\title{
PENGARUH MOTIVASI TERHADAP MINAT MAHASISWA AKUNTANSI MEMILIH MATA KULIAH SAP-FINANCIAL
}

\author{
Oleh: \\ Isti Rahayu " \\ Rizki Restuwardani ")
}

\section{ABSTRAKSI}

Penelitian ini dilakukan untuk mengetahui pengaruh motivasi kualitas dan motivasi karir terhadap minat mahasiswa akuntansi dalam memilih Mata Kuliah Pilihan SAP-Financial. Penelitian ini dilakukan dengan metode purposive sampling dengan sampel berjumlah 89 responden.

Hasil penelitian ini menunjukkan bahwa variabel motivasi kualitas dan motivasi karir berpengaruh positip terhadap minat mahasiswa akuntansi untuk memilih mata kuliah SAP Financial.

Keywords : motivasi kualitas, motivasi karir, minat

\section{A. PENDAHULUAN}

Akuntansi merupakan salah satu Program Studi di Fakultas Ekonomi yang banyak diminati mahasiswa. Hasil penelitian Ariani, 2004 (dalam Tengker, 2007), menyebutkan bahwa rata-rata mahasiswa memilih Program Studi Akuntansi didorong oleh keinginan mereka untuk menjadi profesional di bidang akuntansi. Hal ini juga didorong dengan adanya anggapan bahwa akuntan di masa mendatang akan sangat dibutuhkan oleh organisasi atau perusahaan. Namun demikian dengan banyaknya lufusan Program Studi Akuntansi, membuat persaingan antar lulusan menjadi sedemikian ketat. Untuk itu mahasiswa semakin terpacu untuk membekali dirinya dengan pengetahuan-pengetahuan serta ketrampilan-ketrampilan agar setelah lulus menjadi tenaga kerja siap pakai yang laku di pasaran tenaga kerja, termasuk meningkatkan pengerahuan mereka tentang teknologi informasi yang telah berkembang sangat pesat dewasa ini..

Dengan semakin pesatnya perkembangan teknologi menuntut Program Studi untuk memberikan pendidikan bagi mahasiswanya sesuai dengan perkembangan kebutuhan bisnis terkini. Program Studi Akuntanși Fakuitas Ekonomi Universitas Islam Indonesia merupakan Program Studi Akuntansi pertama di Indonesia yang memasukkan program aplikasi Enterprise Resource

*) Isti Rahayu adalah Dosen Fakultas Ekonomi Universitas Islam Indonesia

**) Rezki Restuwardani adalah Alumni Fakultas Ekonomi Universitas Islam Indonesia 
Isti Rahayu dan Rizki Restuwardani: Pengaruh Motivasi Terhadap Minat Mahasiswa...

Planning (ERP)-System Aplication and Product (SAP) ke dalam Kurikulum. Di Program Studi Akuntansi Universitas Islam Indonesia, SAP-Financial merupakan salah satu Mata Kuliah Pilihan yang sangat diminati mahasiswa. Mata Kuliah ini bisa diambil setelah mahasiswa lulus mata kuliah ERP-SAP Overview.

SAP (System Application and Product) in data processing adalah suatu software yang dikembangkan untuk mendukung suatu brganisasi dalam menjalankan kegiatan operasionainya secara lebih efisien dan efektif. SAP merupakan software Enterprise Resource Planning (ERP) untuk membantu parusahaan merencanakan dan melakukan berbagai aktivitas sehari-hari. SAP terdiri dari sejumlah modul aplikasi yang mempunyai kemampuan mendukung semua transaksi yang terjadi dalam suatu perusahaan. Semua modul aplikasi di SAP bekerja secara terintegrasi atau terhubung satu dengan yang lainnya. Saat ini SAP merupakan program aplikasi yang paling banyak dipergunakan oleh perusahaan-perusahaan di dunia termasuk di Indonesia.

Penelitian ini bertujuan untuk mengetahui apakah terdapat pengaruh motivasi yaitu motivasi kualitas dan motivasi karir, terhadap minat mahasiswa akuntansi untuk memilih mata kuliah SAP Financial.

\section{Motivasi}

Manusia merupakan makhluk hidup yang dalam berbuat atau bertindak terikat oleh faktor-faktor yang datang dari luar dan faktor-faktor yang terdapat dalam diri organisme yang bersangkutan. Faktor penentu dari dalam berupa kekuatan yang datang dari organisme bersangkutan yang menjadi pendorong dalam tindakannya. Dorongan tersebut disebut dengan motivasi.

Susilo, 1987 (dalam Benny dan Yuskar, 2006) menyatakan bahwa motivasi adalah faktor-faktor yang mendorong orang untuk bertindak dengan cara tertentu. Selanjutnya Widyastuti, dkk. (2004) menyatakan bahwa mótivasi seringkali diartikan sebagai dorongan. Dorongan atau tenaga tersebut merupakan gerak jiwa dan jasmani untuk berbuat, sehingga motivasi merupakan suatu tenaga yang menggerakkan manusia untuk bertingkah laku dalam perbuatan yang mempunyai tujuan tertentu.

Banyak sekali motivasi yang melatar belakangi seseorang untuk melakukan sesuatu, dan dalam penelitian ini motivasi yang diduga mendorong mahasiswa untuk memilih mata kuliah SAP Financial adalah motivsi kulitas dan motivasi karir.

Motivasi kualitas merupakan dorongan yang timbul dalam diri seseorang untuk memiliki dan meningkatkan kualitas diri dan kemampuannya dalam bidang yang ditekuninya sehingga dapat melaksanakan tugas dengar baik dan benar (Hapsari, 2007). Peningkatkan kualitas diri dapat dilakukan dengan peningkatan pengetahuan, kecerdasan, kecerdikan, mengembangkan daya analisis yang kuat, mampu bersikap bijaksana, dan meningkatkan moral se ta mental yang lebih baik. Mengambil mata kuliah SAP Financialmerupakan salah satu cara untuk meningkatkan kualitas diri. Mahasiswa akan memperoleh peningkatan pengetahuan maupun pengembangan daya analisis terkait dengan implementasi sistem informasi yang terintegrasi dalam suatu perusahaan.

Menurut Hall, 1986 (dalam Widyastuti, dkk. 2004) karir dapat diartikan sebagai rangkaian sikap dan perilaku yang berhubungan dengan perjalanan 
kerja seseorang sepanjang kehidupan kerjanya. Karir juga dipandang sebagai rangkaian promosi atau transfer lateral untuk memperoleh pekerjaan yang mempunyai beban tanggung jawab lebih tinggi atau penempatan posisi yang lebih baik dalam hirarki pekerjaan seseorang sepanjang kehidupan kerjanya, Cascio dan Awad, 1981 (dalam Widyastuti, dkk. 2004).

Motivasi karir.merupakan dorongan yang timbul dari dalam diri seseorang untuk meningkatkan kemampuan pribadinya dalam rangka mencapai karir yang lebih baik dari sebelumnya (Hapsari 2007). Mahasiswa yang memiliki pengetahuan SAP dengan memilih mata kuliah SAP Financial akan mendapatkan peluang yang lebih besar untuk mendapatkan pekerjaan atau memperoleh kesempatan yang lebih besar untuk dipromosikan, karena SAP merupakan provider software bisnis terbesar yang memiliki market share sekitar $59 \%$, dengan customer lebih dari 43.400 perusahaan di lebih 120 negara. Lebih dari 300 perusahaan di Indonesia sudah mengimplementasikan SAP dan kebutuhan akan tenaga ahli SAP dari tahun ke tahun semakin meningkat sedangkan orang yang memiliki keahlian SAP masih sedikit (Purnomo, 2008).

\section{Minat}

Menurut Widyastuti, dkk. (2004), minat adalah keinginan yang didorong oleh suatu keinginan setelah melihat, mengamati dan membandingkan serta mempertimbangkan dengan kebutuhan yang diinginkannya. Benny dan Yuskar (2006) menyatakan bahwa minat adalah kecenderungan hati yang tinggi terhadap sesuatu.

Minat pada diri individu merupakan hasil dari serangkaian proses. Jika seseorang berminat terhadap sesuatu, maka yang pertama kali dialami adalah pengarahan terhadap objek, subjek atau aktivitas yang merupakan rangsangan bagi diri individu. Berbagai rangsangan tersebut dapat berbentuk benda-benda atau suatu kegiatan. Dari pengenalan ini, akan timbul perasaan sadar pada diri individu bahwa objek, subjek atau aktivitas tersebut bermanfaat bagi dirinya. Perasaan sadar yang didasarkan pada asas manfaat akan diikuti perasaan senang pada objek, subjek atau aktivitas tersebut. Dari kedua rangkain tersebut maka akan terbentuk minat atau tidak.

Teori Acceptance Rejection yang dikemukakan Fryer mengatakan bahwa keberadaan minat itu didasarkan pada orientasi suka dan tidak suka individu terhadap objek, subjek atau aktivitas. Orientasi ini pada gilirannya akan mempengaruhi penerimaan individu. Jika individu suka terhadap suatu objek, subjek atau aktivitas tersebut, maka individu akan menerimanya. Jika individu tidak suka terhadap objek, subjek atau aktivitas maka individu akan menolaknya. Penentuan minat ini didasarkan pada reaksi individu (menolak atau menerima). Jika menerima berarti berminat dan jika menolak berarti tidak berminat.

Oleh karena SAP-merupakan program aplikasi ERP yang paling banyak dipergunakan saat ini dan kebutuhan akan tenaga ahli SAP dari tahun ke tahun semakin meningkat sedangkan orang yang memiliki keahlian SAP masih sedikit (Purnomo, 2008), tentunya dengan memahami program aplikasi SAP akan meningkatkan kesempatan dalam peningkatan karir. 


Berdasarkan teori-teori diatas, diajukan hipotesis:
Ha1: Motivasi kualitas berpengaruh positif terhadap minat masiswaakuntansi
memilih mata kuliah SAP Financial.
Hativasi karir berpengaruh positif terhadap minat mahasiswa akuntansi
mematih muliah SAP Financial.

Populasi pada penelitian ini adalah mahasiswa Program Strata 1 (S1) Program Studi Akuntansi Fakultas Ekonomi Universitas Islam Indonesia. Pengambilan sampel dalam penelitian ini dilakukan secara purposĩve dengan membagikan kuesioner kepada mahasiswa mahasiswa Program Studi Akuntansi yang sudah dan yang sedang mengambil mata kuliah SAP- Financial.

Dari sejumlah 105 kuesioner yang dibagikan, 12 kuesioner diantaranya tidak kembali dan 4 jawaban kuesioner tidak lengkap, sehingga banyaknya sampel yang dapat diolah 89 .

\section{2). Variabel Penelitian}

Variabel dependen pada penelitian ini adalah minat dan variabel independennya adalah motivasi kualitas dan motivasi karir.

\section{a. Motivasi kualitas}

Motivasi kualitas yaitu dorongan yang timbul dari dalam diri seseorang untuk memiliki dan meningkatkan kualitas atau kemampuannya dalam melaksanakan tugas dengan baik. Variabel ini terdiri dari 10 pertanyaan tentang kualitas diri terkait dengan peningkatan pengetahuan, keahlian, kemampuan, pengembangan diri dan sikap mental. Variabel motivasi kualitas diukur dengan skala likert 6 angka, yaitu 1 sampai 6 .

\section{b. Motivasi karir}

Motivasi karir yaitu dorongan yang timbul dari dalam diri seseorang untuk meningkatkan kemampuan pribadinya dalam rangka mencapai karir yang lebih baik dari sebelumnya. Variabel ini terdiri dari 6 pertanyaan tentang karir terkait dengan peluang karir dan kesuksesan di dalam karir. Variabel motivasi karir diukur dengan skala likert 6 angka, yaitu 1 sampai 6.

\section{c. Minat}

Minat adalah kecenderungan hati yang tinggi terhadap sesuatu.Variabel ini terdiri dari 4 pertanyaan tentang minat terkait dengan manfaat yang akan diperoleh dengan memilih SAP Financial. Variabel minat diukur dengan skala likert 6 angka, yaitu 1 sampai 6 dari sangat tidak setuju hingga sangat setuju. 
Selunuh item pertanyaan dalam kuesioneryang digunakan untuk mengukur variabel pada penelitian ini didasarkan pada penelitian Widyastuti (2004), Tengker (2007) dan Hapsari (2007), yang dikembangkan sesuai dengan bahasan penelitian yaitu mata kuliah SAP Financial.

\section{3). Model Penelitian}

Untuk mengetahui pengaruh motivasi kualitas dan motivasi karir terhadap minat, dalam penelitian ini digunakan alat analisis regresi. Model yang digunakan adalah:

$Y=\alpha+\beta 1 X 1+\beta 2 X 2+e$

Keterangan:

$Y$ : minat

$\alpha$ : konstanta.

$\beta$ : koefisien regresi

$\mathrm{X}_{1} \cdot$ : motivasi kualitas

X2 - : motivasi karir

e : errorterm

\section{4). Uji Validitas dan Reliabilitas}

Variabel motivasi kualitas yang terdiri dari 10 pertanyaan dinyatakan valid karena nilai factor loadingnya lebih dari 0,5. Namun terdapat 3 pertanyaan yang tidak mampu mengkonfirmasi variabel dengan baik sehingga direduksi. Dari pengujian reliabilitas nilai cronbach alpha menunjukkan niali 0,881 yang menunjukkan instrumen tersebut reliabel.

Variabel motivasi karir terdiri dari 6 pertanyaan dan seluruhnya dinyatakan valid karena nilai factor loadingnya lebih dari 0,5 dan seluruh pertanyaan mampu mengkonfirmasi variabel dengan baik. Dari pengujian reliabilitas nilai cronbach alpha menunjukkan nilai 0,917 yang menunjukkan instrumen tersebut reliabel.

Variabel minat terdiri dari 4 pertanyaan yang selurụhnya dinyatakan valid dan mampu mengkonfirmasi variabel dengan baik. Dari pengujian reliabilitas nilai cronbach alpha menunjukkan nilai 0,814 yang menunjukkan instrumen tersebut reliabel.

\section{HASIL PENELITIAN}

\section{1). Deskripsi Responden}

Responden dalam penelitian ini berasal dari mahasiswa Program Studi Akuntansi Universitas Isłam Indonesia yang sedang dan yang sudah mengambil mata kuliah SAP Financial, dengan klasifikasi data sebagai berikut: 
Isti Rahayu dan Rizki Restuwardani: Pengaruh Motivasi Terhadap Minat Mahasiswa...

Tabel 1

Klasifikasi Responden Berdasar Angkatan

\begin{tabular}{|c|c|c|}
\hline ANGKATAN & JUMLAH & $\%$ \\
\hline 2004 & 20 & 22,5 \\
\hline 2005 & 69 & 77,5 \\
\hline TOTAL & 89 & 100 \\
\hline
\end{tabular}

Dari hasil pengolahan data di atas dapat diketahui dari 89 responden lebih banyak angkatan 2005, yaitu sebesar 69 mahasiswa dengan persentase $77.5 \%$ dari pada angkatan 2004 sebesar 20 mahasiswa dengan persentase $22.5 \%$. Hal ini terjadi disebabkan saat penelitian dilakukan mahasiswa angkatan tahun 2004 telah banyak yang lulus, sehingga responden lebih bahyak berasal dari mahasiswa angkatan tahun 2005.

Tabel 2

Klasifikasi Responden Berdasar Ġender

\begin{tabular}{|c|c|c|}
\hline PRIAWANITA & JUMLAH & $\%$ \\
\hline PRIA & 39 & $43,8 \%$ \\
\hline WANITA & 50 & $57,2 \%$ \\
\hline
\end{tabular}

Dari hasil pengolahan data di atas dapat diketahui bahwa dari 89 responden (mahasiswa akuntansi) yang mengambil mata kulih SAP Financial lebih banyak mahasiswa perempuan yaitu sebanyak 50 mahasiswa dengan persentase $56,2 \%$, dari pada mahasiswa laki-laki yaitu 39 mahasiswa dengan persentase $43,8 \%$.

\section{2). Statistik Deskriptif}

Statistik deskriptif memberikan gambaran atau deskripsi suatu data yang dilihat dari nilai rata-rata (mean), standar deviasi, maksimum, minimum masingmasing variabel. Hasil statistik deskriptif data adalah sebagai berikut:

Tabel 3

Statistik Deskriptif Variabel

\begin{tabular}{|c|c|c|c|c|c|}
\hline VAR & $\mathrm{N}$ & Maks & Min & Mean & St. Dev \\
\hline Minat & 89 & 6 & 1.75 & 4.6433 & .84434 \\
\hline $\begin{array}{c}\text { Motivasi } \\
\text { Karir }\end{array}$ & 89 & 6 & 1,5 & 4.3727 & .92114 \\
\hline $\begin{array}{c}\text { Motivasi } \\
\text { Kualitas }\end{array}$ & 89 & 5.7 & 1.8 & 4.5202 & .75275 \\
\hline
\end{tabular}


Dari tabel di atas, dapat dijelaskan bahwa niali rata-rata (mean) variabel minat 4.6433, motivasi karir sebesar 4,3727, dan motivasi kualitas sebesar 4.502. Hal ini menunjukkan rata-rata dari 89 responden sangat berminat terhadap mata kuliah SAP Financial. Responden juga setuju bahwa motivasi karir dan kualitas mempengaruhi mereka untuk memilih mata kuliah SAP Financial.

Tabel 4

Hasil Regresi

\begin{tabular}{|c|c|c|c|c|c|c|}
\hline \multirow[b]{2}{*}{ Model } & & $\begin{array}{c}\text { Unstandardized } \\
\text { Coefficients }\end{array}$ & $\begin{array}{l}\text { Standardized } \\
\text { - Coefficients } \\
\end{array}$ & $\mathrm{T}$ & \multirow[b]{2}{*}{ Sig. } & \multirow[b]{2}{*}{ Prob } \\
\hline & & B & Std. Error & Beta & & \\
\hline \multirow[t]{3}{*}{1} & (Constant) & 1,359 & ,395 & & 3,444 & ,001 \\
\hline & kualitas & 240 & ,115 & ,214 & 2,087 &, 040 \\
\hline & karir & ,502 &, 094 &, 548 & 5,336 &, 000 \\
\hline
\end{tabular}

a Dependent Variable: minat

Dari hasil uji regresi sebagaimana tampak dalam table 4, maka hipotesis pertama terbukti karena tingkat signifikansi $0,040<$ alpha 0,05 yang artinya Ha1 diterima, dengan koefisien Beta positip. Dengan demikian hipotesis pertama yang menyatakan motivasi kualitas berpengaruh positif terhadap minat mahasiswa akuntansi untuk memilih mata kuliah SAP-Financial adalah terbukti. Artinya mahasiswa akuntansi akan semakin berminat untuk memilih mata kuliah SAP Financial karena dapat meningkatkan kualitas diri dan kemampuannya dalam bidang akuntansi sehingga dapat menjalankan tugasnya dengan baik.

Dari hasil uji regresi hipotesis kedua juga terbukti, karena tingkat signifikansi $0,000<$ alpha 0,05 sehingga $\mathrm{Ha} 2$ diterima, dengan koefisien beta positip. Dengan demikian dapat disimpulkan bahwa hipotesis kedua yang menyatakan motivasi karir berpengaruh positif terhadap minat mahasiswa akuntansi untuk memilih mata kuliah SAP Financial adalah terbukti. Artinya mahasiswa akuntansi akan semakin berminat untuk memilih mata kuliah SAP Financialkarena dapat memberikan peluang yang besar bagi dirinya untuk mendapatkan pekerjaan serta dapat membantu dalam mendapatkan keempatan promosi jabatan atas prestasi yang dihasilkan. Hal ini dimungkinkan karena sekarang telah banyak perusahaan yang mengimplementasikan SAP sedangkan Sumber Daya Manusia yang memiliki pengetahuan SAP masih terbatas.

\section{KESIMPULAN DAN SARAN}

Berdasarkan analisis data dalam penelitian ini dapat disimpulkan bahwa motivasi kualitas dan motivasi karir terbukti mempengaruhi secara positip minat mahasiswa akuntansi untuk memilih mata kuliah SAP Financial. 
Isti Rahayu dan Rizki Restuwardani: Pengaruh Motivasi Terhadap Minat Mahasiswa...

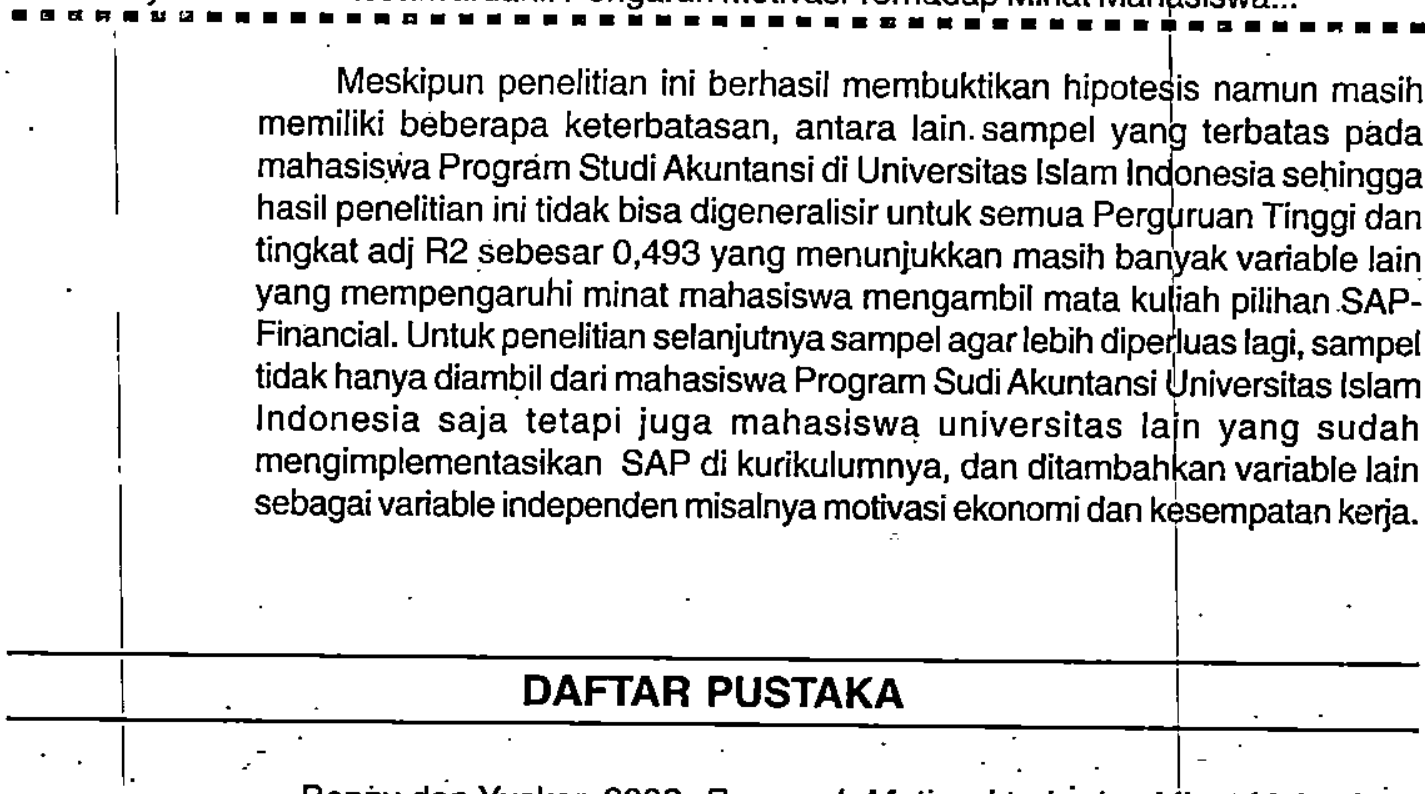

Benny dan Yuskar, 2006, Pengaruh Motivasi terhadap Minat Mahiasiswa Akuntansi Untuk Mengikuti Pendidikan Profesi Akuntansi (PPAk), Simposium Nasioanal Akuntansi IX.

Buku Pedoman Akademik 2008-2009 Fakultas Ekonomi Universitas Islam Indonesia.

Dhewanto dan Falahah, 2007, ERP (Enterprise Resource Planning) Menyelaraskan teknologi Informasi dengan StrategiBisnis, Informatika Bandung. Bandung.

Ghozali, Imam, 2005, Aplikasi Analisis Multivariate dengan Program SPSS, Badan Penerbit Universitas Diponegoro, Semarang.

Hamzah, Ardi, 2008, Perbedaan Persepsi mahasiswa Akuntansi Mengenai Sosiologi Kritis, Kreatifitas, dan Mentalitas, Simposium Nasional Akuntansi XI.

Hapsari, Aryani, 2007, Pengaruh Motivasi terhadap Minat Mahasiswa Akuntansi Untuk Mengikuti Pendidikan Profesi Akuntansi (PPAk), Skripsi S-1 Fakultas Ekonomi UII.

Hasibuan, Malayu S.P., 2005, Organisasi dan Motivasi, PT. Bumi Aksara, Jakarta.

http://informatika.fti-uii.org, 22 November 2008.

. Ikhsan dan Ishak, 2005, Akuntansi Keperilakuan, Salemba Empat, Jakarta.

Mowen, C., John dan Minor, 2002, Consumer Behaviour(Terjemahan), Edisi Kelima, PT Penerbit Erlangga, Jakarta. 
Purnomo, Arief, 2008, Becoming A Bussiness Engineer With SAP, Artikel STT Telkom.

Santoso, Singgih, 2003, Mengatasi berbagaiMasalah Statistik dengan SPSS,

PT Elex Media Komputindo, Jakarta

Sekaran, Uma, 2006, Research Methods for Business, Edisi Keempat, Salemba Empat, Jakarta.

Tengker dan Morasa, 2007, Pengaruh Motivasi Karir Terhadap Minat Mahasiswa Akuntansi Untuk Mengikuti Pendidikan Profesi Akuntansi (PPAk), Jurnal penelitian Unsrat Manado.

Usmara, 2006, Motivasi Kerja "Proses, Teori, dan Praktik", Amara Books. Yogyakarta.Widyastuti, Suryaningsum dan Juliana, 2004, Pengaruh Motivasi Terhadap Minat Mahasiswa Akuntansi Untuk Mengikuti Pendidikan Profesi Akuntansi (PPAk), Simposium Nasional Akuntansi VII.

www.uii.ac.id, 20 November 2008

\section{KUESIONER}

\section{Motivasi Kualitas}

Pernyataan-pernyataan di bawah ini berkaitan dengan motivasi Saudara/ i mengenai kualitas diri yang ingin dicapai dengan memilih mata kuliah SAP Fianancial.

1. Untuk mendapatkan pengetahuan tenang modul SAP Financial yang telah banyak diaplikasikan di perusahaan-perusahaan besar.

2. Untuk mendapatkan keahlian mengunakan SAP Financial dalam proses bisnis perusahaan.

3. Untuk meningkatkan kemampuan organisasional dalam lingkungan bisnis.

4. Untuk meningkatkan kemampuan analitis, decision making, dan problem solving.

5. Untuk meningkatkan kemampuan bekerjasama dalam kelompok.

6. Untuk meningkatkan kemampuan berkomunikasi.

7. Untuk meningkatkan kemampuan dalam mencostomize modul SAP Financial.

8. Untuk mampu menyelesaikan beban pekerjaan yang diberikan dengan baik.

9. Untuk meningkatkan rasa profesionalisme dan kebanggaan.

10. Untuk meningkatkan rasa tanggung jawab dalam pekerjaan. 
Isti Rahayu dan Rizki Restuwardani: Pengaruh Motivasi Terhadap Minat Mahasiswa...

\section{Motivasi Karir}

Pernyataan-pernyataan di bawah ini berkaitan dengan motivasi Saudara/ i méngenai kesuksesan karir yang ingin dicapai dengan memilih mata kuliah SAP Fianancial.

1. Untuk mendapatkan pekerjaan sesuai latar belakang pendidikan.

2. Untuk meningkatkan kesempatan promosi jabatan.

3. Untuk mendapatkan pengakuan profesional dari atasan, rekan dan bawahan di lingkungan kerja.

4. Untuk meningkatkan kemampuan berprestasi di dalam pekerjan.

5. Untuk memperluas akses dan jaringan dengan dunia kerja.

6. Untuk mendapatkan pengetahuan berkaitan dengan peran dan tanggung jawab yang akan dimiliki ketika berada di perusahaan.

\section{Minat}

Pernyataan-pernyataan di bawah ini berkaitan dengan minat Saudara/i untuk memilih mata kuliah SAP Financial.

1. Saya memilih SAP Financial karena dapat meningkatkan kualitas diri.

2. Saya memilih SAP Financial karena dapat menunjang kesuksesan karir.

3. Saya memilih SAP Financial karena ingin tahu bagaimana SAP Financial diimplementasikan di perusahaan.

4. Saya memilih SAP Financial karena akan mendapatkan sertifikat yang dikeluarkan oleh pihak eksternal. 